\title{
Liver Cancer pT3 TNM Finding v6
}

National Cancer Institute

\section{Source}

National Cancer Institute. Liver Cancer pT3 TNM Finding v6. NCI Thesaurus. Code C61173.

Liver cancer with multiple tumors at least one of which is more than $5 \mathrm{~cm}$ in size, or a tumor involving a major branch of the portal or hepatic vein. (from AJCC 6th Ed.) 